\title{
Effects of Betaine and Chitin on Water Use Efficiency in Lettuce (Lactuca sativa var. capitata)
}

\author{
Furn-Wei Lin, Kuan-Hung Lin, Chun-Wei Wu, and Yu-Sen Chang \\ Department of Horticulture and Landscape Architecture, National Taiwan \\ University, Taipei 106, Taiwan
}

\section{Kuan-Hung Lin \\ Department of Horticulture and Biotechnology, Chinese Culture University, Taipei 111, Taiwan}

Chun-Wei Wu

Department of Horticulture, National Ilan University, Yilan 260, Taiwan

Additional index words. biostimulants, irrigation water requirement, regulated deficit irrigation, water-saving agriculture, water stress

\begin{abstract}
Plant biostimulants have received increasing attention in recent years because of their positive effects on crop performance and contribution to agro-ecological sustainability. The aim of this study was to determine the influence of betaine and chitin treatments, alone and in combination, on lettuce plants by changes in the morphology and physiology of plants exposed to regulated deficit irrigation (RDI). Plants were subjected to full irrigation (FI; no water deficiency treatment, field capacity $>70 \%$ ) and RDI (field capacity $<50 \%$ ) conditions until the end of each experiment. We recorded plant yield-related traits, net photosynthesis, and water use efficiency (WUE) values weekly for 4 weeks and carried out three individual experiments to assess the efficacy of biostimulant and irrigation treatments. Betaine $(0,50$, and $100 \mathrm{~mm} /$ plant) was foliartreated every 2 weeks during Expt. 1, whereas chitin $(0,2$, and $4 \mathrm{~g} / \mathrm{kg})$ was applied to the soil at the beginning of Expt. 2. We then applied the optimal concentration of each chemical alone or in combination to the plants as Expt. 3. Compared with negative control, the application of $50 \mathrm{~mm}$ betaine and $2 \mathrm{~g} / \mathrm{kg}$ chitin significantly increased leaf area (LA) per plant by $48.5 \%$ and $25.6 \%$, respectively. Furthermore, 50 mu betaine and $2 \mathrm{~g} / \mathrm{kg}$ chitin treatment showed a clearly protective effect in RDI plants, enhancing their total fresh weights by $\mathbf{2 6 . 1 0 \%}$ and $\mathbf{7 5 . 0 \%}$, respectively, in comparison with control. Comparing WUE $E_{\text {yield }}$ and $W U E_{\text {biomass, }}$ chemical-treated plants had higher values than control. Betaine (50 mM) or chitin $(2 \mathrm{~g} / \mathrm{kg})$ treatments alone significantly elevated $\mathrm{LA}$, fresh shoot weight, total fresh and dry weights, net photosynthesis, and WUE values, and boosted the water stress tolerance of lettuce under RDI compared with controls. However, a combined treatment of $50 \mathrm{~mm}$ betaine and $2 \mathrm{~g} / \mathrm{kg}$ chitin did not increase the levels of all yield traits under RDI compared with individual chemical treatment. Most leaves appeared healthy, green, and had visually less leaf chlorosis when treated with chitin or betaine under RDI compared with untreated plants subjected to RDI. Our study indicates that applying betaine and chitin improves plant performance against water supply limitations and highlights their potential for the sustainable production of lettuce.
\end{abstract}

Irrigated agriculture currently delivers $40 \%$ of the world's food supply from just $20 \%$ of the cultivated land, and provides crucial stability for global food security (Garces-Restrepo and Giovanni, 2008). Using water sparingly can be an efficient way to maintain the sustainability of water re-

Received for publication 30 Aug. 2019. Accepted for publication 7 Oct. 2019.

Published online 10 December 2019

F.W.L. and K.H.L. contributed equally to this work.

C.W.W. and Y.S.C. are the corresponding authors. E-mail: r88628115@ntu.edu.tw or yschang@ntu. edu.tw.

This is an open access article distributed under the CC BY-NC-ND license (https://creativecommons.org/ licenses/by-nc-nd/4.0/) technology that tries to ensure an optimal crop water status in the phenological phases most sensitive to water stress and restrict irrigation in the most resistant crop phases (Galindo et al., 2018; Marsal et al., 2016). It is particularly useful in areas where water is drastically restricted during summer months because of severe drought or priorities for urban use (Fereres et al., 2012). RDI has a great impact on the growth, development, yield, and quality of crops, and usually improves WUE in waterstressed areas (Chai et al., 2016; Rop et al., 2016). Understanding and evaluating a plant's ability to cope with water stress in specific/ localized environments will lead to betterinformed decisions on the suitability of irrigation management practices.

Lettuce (Lactuca sativa L. var. capitata), a member of the Asteraceae family, is cultivated worldwide and is one the most consumed rosette leafy vegetables in the raw form for its taste and high nutritive value. Lettuce is an excellent source of vitamins, iron, folate, caffeic acid, carotenoids, and other antioxidants (Malejane et al., 2018; Sonmez et al., 2017). Different varieties of lettuce are distinguished by their morphology and end users. They grow well both in the open field and under protection and some can adapt well to warm conditions or hot weather (Şenyiğit and Kaplan, 2013). The major problem during lettuce cultivation is the requirement for a large quantity of water, and it is extremely sensitive to deficit irrigation and drought because of its short root system (Malcom et al., 2012; Şenyiğit and Kaplan, 2013). Therefore, new strategies will become critical to enhance productivity under deficit irrigation. Previous studies demonstrated that a water deficit of $30 \%$ to $\approx 40 \%$ drastically reduces lettuce fresh weight and final production and increases oxidative damage (Jiménez-Arias et al., 2019; Sayyari et al., 2013). For the past several years, numerous techniques have been applied to overcome water deficit in field crops. Strategies to mitigate losses or damage due to inadequate water allow for the study and development of tolerant genotypes and application of biostimulants that induce water-deficit tolerance in plants (Calvo et al., 2014). Our study investigated the impact of plant biostimulants on the growth of the lettuce during RDI.

Plant biostimulants, such as betaine and chitin, are natural constituents and metabolites of plants and microorganisms that affect the crop itself and do not harm the environment because of their biodegradable and nontoxic nature (Patrick, 2015). The use of small quantities of biostimulants to enhance crop growth and yield and limit the effects of stress on plants has gained considerable momentum for ecological sustainability and consumer health (du Jardin, 2015). Plant biostimulants contain active humic substances and nitrogen compounds of natural origin that also intensify water uptake and nutrient transport and stimulate photosynthesis (Pruszyński, 2008). Chitin is composed of $\beta(1,4)$-linked units of $\mathrm{N}$-acetyl-dglucosamine. Betaine is a fully N-methyl- 
substituted derivative of glycine that is widely distributed in plants, animals, and microbes (Ahmad et al., 2013). Betaine and chitin have several beneficial roles in different plant species under abiotic stress and can act as elicitors to address stress adaptation (Hidangmayum et al., 2019; Rady et al., 2018). Studies of chitin and its derivatives (i.e., chitosan glycine) that induce resistance mechanisms under stressing have been used in plants to confer resistance against water deficit, salinity, heat stress, and heavy metal toxicity (Sharif et al., 2018). Betaine has multiple biological functions, including the maintenance of cellular water balance via osmotic adjustment (You et al., 2019). Although there is a growing interest and use of biostimulants by growers, research documenting the impacts of biostimulants on lettuce development remain insufficient. No reports have shown that betaine and chitin had protective effects in lettuce under RDI treatments, and the mechanisms of action of these two biostimulants on the growth and physiological processes of RDI lettuce remain unknown. This study assessed the feasibility of using those two biostimulants to save water and increase lettuce yields. We hypothesized that betaine- and chitin-treated plants would be capable of inducing waterdeficit tolerance while increasing the yield and WUE of plants under RDI. The objectives of this study were to evaluate and compare the effects of optimal concentrations of betaine and chitin on yield components, net photosynthesis, and WUE values of lettuce under RDI and FI conditions. Our results explore the effects of RDI in combination with two biostimulants to save water while benefiting lettuce production, thus providing fundamental research and a reference point for irrigation management decisions for agriculture in semiarid areas.

\section{Materials and Methods}

Plant material and experimental site. Seeds of lettuce (Lactuca sativa var. capitata cv. Fukuyama) were purchased from KnownYou Seed Co. (Taipei, Taiwan) for our experiments. This cultivar is an $F_{1}$ hybrid, one of the most popular of the lettuces grown in Taiwan in all seasons, and also is the most economically important, abundant, and consumed salad crop in Taiwan as well. Seeds were germinated and grown in 200-cell flats $(60 \times 30 \mathrm{~cm}, 3.0 \times 3.0 \times 3.5 \mathrm{~cm}$ each cell $)$ for 1 week. The soil used was a commercial potting mix of peatmoss, perlite, and vermiculite $(3: 1: 1 \mathrm{v} / \mathrm{v} / \mathrm{v})$. The seedlings were then transplanted into free-draining polyethylene plastic pots $(12 \mathrm{~cm}$ diameter, $11 \mathrm{~cm}$ depth, one plant per pot), and $165 \mathrm{~g}$ of the previously mentioned medium was added to each pot. All seedlings were grown in an environmentcontrolled greenhouse at National Taiwan University (lat. $25.01^{\circ} \mathrm{N}$ ) for 1 week. All plants were fully watered in the evening, maintaining good soil moisture until RDI and biostimulants were imposed. Those of a relatively uniform size were selected and randomly separated into different groups for the RDI and biostimulant experiments. The growth environment was controlled to a 14/ $10 \mathrm{~h}$ day/night photoperiod at $28 / 22{ }^{\circ} \mathrm{C}$ with a relative humidity of $75 \%$ and $300 \mu \mathrm{mol} \cdot \mathrm{m}^{-2} \cdot \mathrm{s}^{-1}$ photosynthetic photon flux.

Irrigation treatments and biostimulant applications. All plants were irrigated until gravitational water was released before the experiments started. Plants were then subjected to two irrigation levels differentiated by the amount of irrigation water applied over the 30-d experimental period. They included an FI treatment (no water deficiency, field capacity $>70 \%$ ) as the control and RDI treatment (field capacity $<50 \%$ ). After irrigation, a soil moisture sensor (WET Sensor, Type HH2; Delta-T Device, Cambridge, UK) was used to monitor and record the field capacity of all treatments in all pots every day throughout the experiment.

Biostimulants were applied to each plant to study their responses to water stress. Three concentrations of betaine (B2626; Sigma, San Diego, CA) aqueous solutions (dissolved in distilled deionized water) at 0,50 , and $100 \mathrm{~mm} /$ plant were sprayed onto plant leaves with a handheld power sprayer until saturated. Betaine was foliar-treated every 2 weeks during Expt. 1 from 21 May to 20 June 2018. Moreover, three concentrations of chitin (C7170; Sigma) at 0, 2, and $4 \mathrm{~g} / \mathrm{kg}$ were applied to the top $5 \mathrm{~cm}$ soil layer of each pot. Chitin was added to the soil once in the beginning of Expt. 2, which ran from 23 May to 22 June 2018. After investigating the differences in the two individual chemical treatments used in Expts. 1 and 2, the optimal concentration of each chemical alone or in combination was also applied to the plants (Expt. 3, 1 July to 30 July 2018). All plants tested in Expt. 3 were subjected to the same experimental procedure as used during Expts. 1 and 2 . The concentrations of the chemical solutions were selected based on data from our preliminary study (data not shown). Plants without biostimulant treatment in the FI condition were considered controls to provide a basis for comparison with the effects of the biostimulants under FI and RDI. In each experiment, all plants from FI or RDI were harvested at the same time of day and used for yield components and WUE measurement.

Data collection and analysis. All plants were manually watered once a day in the late afternoon at $100 \%$ of the transpiration rate. Six plants (per replicate) of each irrigation treatment were arranged in a completely randomized design, totaling 36 pots (one plant per pot) each in Expts. 1 and 2 and 30 pots in Expt. 3. We measured the phenotypic traits and WUE of six randomly selected representative plants from each biostimulant treatment in each irrigation treatment. All analyses were performed weekly until the end of the 4-week experimental period:

1. Healthy, fully expanded mature leaves of each plant were used to determine LA using a portable LAI-3000C Plant
Canopy Analyzer (LI-COR, Lincoln, NE).

2. Plant height, measured as the height (cm) above the soil.

3. Fresh weight of shoots and roots, measured as green shoots and roots, and clipped at the soil surface to assess biomass accumulation.

4. Fresh weight and dry weight at harvest, followed by drying in an oven at $70^{\circ} \mathrm{C}$ for $6 \mathrm{~d}$.

5. WUE parameters were calculated per treatment using the following formulae:

(1) Intrinsic WUE (WUE $)_{i}$ (Wakrim et al., 2005) was evaluated by calculating the net photosynthetic rate $\left(\mu \mathrm{mol} \cdot \mathrm{m}^{-2} \cdot \mathrm{s}^{-1}\right.$ $\mathrm{CO}_{2}$ ) divided by the transpiration rate $\left(\mathrm{mmol} \cdot \mathrm{m}^{-2} \cdot \mathrm{s}^{-1} \mathrm{H}_{2} \mathrm{O}\right)$. Transpiration and net photosynthetic rate of the third or fourth mature and expanded leaves (with an LA of $1 \mathrm{~cm}^{2}$ ) were determined using a portable photosynthesis system (GFS-3000;Walz, Effeltrich, Germany) from 1000 to $1600 \mathrm{HR}$ in a typical irrigation period. The measurement was conducted in the previously mentioned environmentally controlled room under $25^{\circ} \mathrm{C}$ and $900 \mu \mathrm{mol} \cdot \mathrm{m}^{-2} \cdot \mathrm{s}^{-1}$ with a relative humidity of $70 \%$ and $\mathrm{CO}_{2}$ of $400 \mathrm{ppm}$.

(2) WUE $\mathrm{E}_{\text {yield }}$ was calculated as the fresh weight of shoots $(\mathrm{g})$ per treatment divided by the total irrigation water supplied $\left(\mathrm{m}^{-3}\right)$.

(3) WUE $_{\text {biomass }}$ was calculated as the total dry weight $(\mathrm{g})$ per treatment divided by the total irrigation water supplied $\left(\mathrm{m}^{-3}\right)$.

Statistical analysis. The measurements of phenotypic traits were analyzed by a completely randomized analysis of variance (ANOVA) that compared the different irrigation and biostimulant treatments for each parameter. Two-factor ANOVA was used to analyze growth and yield data and photosynthetic parameters, as well as the WUE data, with biostimulants and irrigation considered as two fixed effects. For significant values, means were separated by the least significant difference test at $P \leq 0.05$ using Costat 6.29 (CoHort Software, Berkeley, CA).

\section{Results and Discussion}

Comparisons between betaine-treated and-untreated plants under FI and RDI. Tables 1 and 2 illustrate that applying betaine as a foliar spray alters the morphophysiological and WUE responses of lettuce under RDI. The effects of betaine concentrations (B) on lettuce growth and yield under irrigation conditions (I) displayed significant differences $(P \leq 0.001,0.01$, and 0.05$)$ by the main effects and the interaction effect $(\mathrm{I} \times \mathrm{B})$ in LA and shoot and total fresh weight (Table 1). However, there were no significant differences in plant height, fresh root weight, and dry weight in all effects, except for plant height and dry weight, which showed a significant difference in the FI effect. 
Table 1. Effects of different concentrations of betaine on the yield performance of lettuce under full irrigation (FI) and regulated deficit irrigation (RDI).

\begin{tabular}{|c|c|c|c|c|c|c|c|c|c|}
\hline \multirow[b]{2}{*}{$\begin{array}{l}\text { Irrigation } \\
\text { treatment }\end{array}$} & \multirow[b]{2}{*}{$\begin{array}{c}\text { Betaine concn } \\
(\mathrm{mm})\end{array}$} & \multicolumn{2}{|c|}{ Plant ht $(\mathrm{cm})$} & \multirow[b]{2}{*}{ Leaf area $\left(\mathrm{cm}^{2}\right)$} & \multicolumn{3}{|c|}{ Fresh wt (g/plant) } & \multirow[b]{2}{*}{$\begin{array}{c}\text { Total dry wt } \\
\text { (g/plant) }\end{array}$} & \multirow[b]{2}{*}{$\begin{array}{c}\text { Total water } \\
\text { irrigation }\left(\mathrm{cm}^{3}\right)\end{array}$} \\
\hline & & 0 weeks & 4 weeks & & Shoot & Root & Total & & \\
\hline FI & 0 & $11.83 \mathrm{a}$ & $19.27 \mathrm{ab}$ & $732.26 \mathrm{~b}$ & $31.85 \mathrm{~b}$ & $3.58 \mathrm{a}$ & $35.42 \mathrm{~b}$ & $2.32 \mathrm{a}$ & 1140 \\
\hline FI & 50 & $11.67 \mathrm{a}$ & $19.37 \mathrm{ab}$ & $882.30 \mathrm{a}$ & $38.72 \mathrm{a}$ & $4.13 \mathrm{a}$ & $42.84 \mathrm{a}$ & $2.43 \mathrm{a}$ & 995 \\
\hline FI & 100 & $11.68 \mathrm{a}$ & $20.07 \mathrm{a}$ & $748.35 \mathrm{~b}$ & $33.37 \mathrm{~b}$ & $4.19 \mathrm{a}$ & $37.56 \mathrm{~b}$ & $2.36 \mathrm{a}$ & 1055 \\
\hline RDI & 0 & $11.77 \mathrm{a}$ & $16.82 \mathrm{c}$ & $477.24 \mathrm{~d}$ & $25.76 \mathrm{c}$ & $3.78 \mathrm{a}$ & $28.08 \mathrm{c}$ & $1.94 \mathrm{~b}$ & 660 \\
\hline RDI & 50 & $11.83 \mathrm{a}$ & $18.90 \mathrm{~b}$ & $708.50 \mathrm{~b}$ & $30.60 \mathrm{~b}$ & $3.82 \mathrm{a}$ & $35.40 \mathrm{~b}$ & $2.37 \mathrm{a}$ & 530 \\
\hline RDI & 100 & $11.93 \mathrm{a}$ & $19.08 \mathrm{ab}$ & $658.42 \mathrm{c}$ & $27.51 \mathrm{c}$ & $4.01 \mathrm{a}$ & $31.52 \mathrm{c}$ & $2.26 \mathrm{a}$ & 495 \\
\hline \multicolumn{10}{|c|}{ Source of variation } \\
\hline \multicolumn{3}{|c|}{ Irrigation treatments (I) } & * & $* * *$ & $* *$ & NS & $* *$ & $*$ & $* * *$ \\
\hline \multicolumn{3}{|c|}{ Betaine concentration (B) } & NS & $* *$ & $*$ & NS & $*$ & NS & $*$ \\
\hline \multicolumn{2}{|c|}{$\mathrm{I} \times \mathrm{B}$} & & NS & $*$ & $*$ & NS & $*$ & NS & $*$ \\
\hline
\end{tabular}

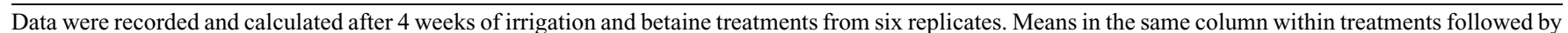

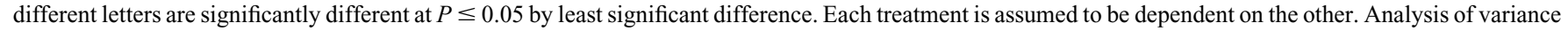

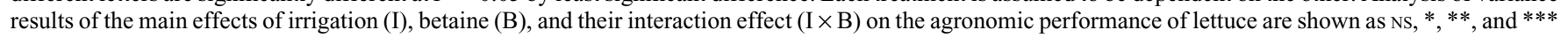
as nonsignificant or significant at $P \leq 0.05,0.01$, or 0.001 , respectively.

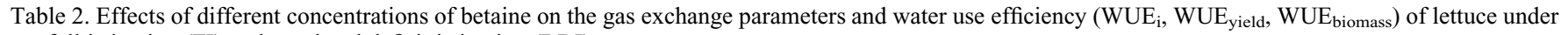
full irrigation (FI) and regulated deficit irrigation (RDI).

\begin{tabular}{|c|c|c|c|c|c|c|c|c|c|}
\hline \multirow[b]{2}{*}{$\begin{array}{l}\text { Irrigation } \\
\text { treatment }\end{array}$} & \multirow[b]{2}{*}{$\begin{array}{c}\text { Betaine } \\
\text { concn }(\mathrm{mm})\end{array}$} & \multicolumn{2}{|c|}{0 weeks } & \multicolumn{2}{|c|}{4 weeks } & \multirow[b]{2}{*}{$\begin{array}{l}\text { Net photosynthesis } \\
\left(\mu \mathrm{mol} \cdot \mathrm{m}^{-2} \cdot \mathrm{s}^{-1}\right. \\
\left.\mathrm{CO}_{2}\right)\end{array}$} & \multirow[b]{2}{*}{$\begin{array}{c}\text { WUEi } \\
(\mu \mathrm{mol} \\
\left.\mathrm{CO}_{2} / \mathrm{mmol} \mathrm{H}_{2} \mathrm{O}\right)\end{array}$} & \multirow[b]{2}{*}{$\begin{array}{l}\text { WUE }_{\text {yield }} \\
\left(\mathrm{kg} \cdot \mathrm{m}^{-3}\right)\end{array}$} & \multirow[b]{2}{*}{$\begin{array}{c}\text { WUE }_{\text {biomas }} \\
\left(\mathrm{kg} \cdot \mathrm{m}^{-3}\right)\end{array}$} \\
\hline & & $\begin{array}{c}\text { Transpiration } \\
\left(\mathrm{mmol} \cdot \mathrm{m}^{-2} \cdot \mathrm{s}^{-1}\right. \\
\left.\mathrm{H}_{2} \mathrm{O}\right)\end{array}$ & $\begin{array}{c}\text { Net photosynthesis } \\
\left(\mu \mathrm{mol} \cdot \mathrm{m}^{-2} \cdot \mathrm{s}^{-1}\right. \\
\left.\mathrm{CO}_{2}\right)\end{array}$ & $\begin{array}{c}\mathrm{WUE}_{\mathrm{i}}(\mu \mathrm{mol} \\
\mathrm{CO}_{2} / \mathrm{mmol} \\
\left.\mathrm{H}_{2} \mathrm{O}\right)\end{array}$ & $\begin{array}{c}\text { Transpiration } \\
\left(\mathrm{mmol} \cdot \mathrm{m}^{-2} \cdot \mathrm{s}^{-1}\right. \\
\left.\mathrm{H}_{2} \mathrm{O}\right)\end{array}$ & & & & \\
\hline$\overline{\text { FI }}$ & 0 & $0.97 \mathrm{a}$ & $9.05 \mathrm{a}$ & $11.01 \mathrm{a}$ & $1.03 \mathrm{a}$ & $10.10 \mathrm{~b}$ & $10.34 \mathrm{~b}$ & $31.07 \mathrm{c}$ & $2.07 \mathrm{~b}$ \\
\hline FI & 50 & $0.96 \mathrm{a}$ & $8.70 \mathrm{a}$ & $10.42 \mathrm{a}$ & $1.07 \mathrm{ab}$ & $13.24 \mathrm{a}$ & $12.85 \mathrm{~b}$ & $43.06 \mathrm{~b}$ & $2.44 \mathrm{~b}$ \\
\hline FI & 100 & $0.92 \mathrm{a}$ & $8.92 \mathrm{a}$ & $9.73 \mathrm{a}$ & $1.17 \mathrm{ab}$ & $12.57 \mathrm{a}$ & $12.40 \mathrm{~b}$ & $35.60 \mathrm{c}$ & $2.20 \mathrm{~b}$ \\
\hline RDI & 0 & $0.93 \mathrm{a}$ & $8.55 \mathrm{a}$ & $10.39 \mathrm{a}$ & $0.31 \mathrm{c}$ & $6.80 \mathrm{~d}$ & $37.10 \mathrm{a}$ & $46.33 \mathrm{~b}$ & $2.94 \mathrm{~b}$ \\
\hline RDI & 50 & $0.94 \mathrm{a}$ & $8.35 \mathrm{a}$ & $9.52 \mathrm{a}$ & $0.92 \mathrm{ab}$ & $10.89 \mathrm{~b}$ & $12.02 \mathrm{~b}$ & $64.87 \mathrm{a}$ & $4.43 \mathrm{a}$ \\
\hline RDI & 100 & $0.90 \mathrm{a}$ & $8.24 \mathrm{a}$ & $11.34 \mathrm{a}$ & $0.74 \mathrm{~b}$ & $9.42 \mathrm{c}$ & $15.51 \mathrm{~b}$ & $63.68 \mathrm{a}$ & $4.57 \mathrm{a}$ \\
\hline \multicolumn{10}{|c|}{ Source of variation } \\
\hline \multicolumn{2}{|c|}{ Irrigation treatment (I) } & & & & $* * *$ & $* * *$ & $*$ & $* * *$ & $* *$ \\
\hline \multicolumn{2}{|c|}{ betaine concentration (B) } & & & & NS & $* *$ & $*$ & $* *$ & $*$ \\
\hline \multicolumn{2}{|c|}{$\mathrm{I} \times \mathrm{B}$} & & & & $*$ & $*$ & NS & $*$ & * \\
\hline
\end{tabular}

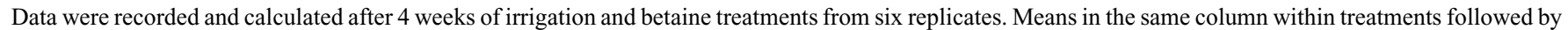

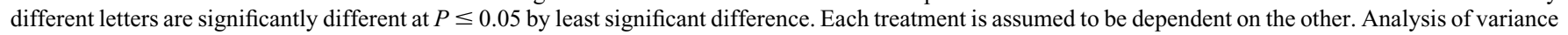
results of the main effects of irrigation (I), betaine (B), and their interaction effect $(\mathrm{I} \times \mathrm{B})$ on gas exchange parameters and WUE values of lettuce are shown as Ns, $*, * *$, and $* * *$ as nonsignificant or significant at $P \leq 0.05,0.01$, or 0.001 , respectively.

Significantly higher growth trait values were detected (except fresh root weight) in plants subjected to $50 \mathrm{~mm}$ betaine compared with $100 \mathrm{~mm}$ betaine treatment and its control (nobetaine treatment) under RDI. LA (708.50 $\left.\mathrm{cm}^{2}\right)$ and total fresh weight (35.40 g/plant) of the plants sprayed by $50 \mathrm{~mm}$ of betaine under RDI were significantly increased by $48.5 \%$ and $26.10 \%$, respectively, compared with nobetaine treatment under RDI (LA $477.24 \mathrm{~cm}^{2}$ and total fresh weight $28.08 \mathrm{~g} / \mathrm{plant}$ ). Betaine appears to promote water stress tolerance effects in RDI lettuce plants. Figure 1A displays that most leaves appeared healthy and green when foliar-treated with $50 \mathrm{~mm}$ betaine under RDI compared with betaineuntreated plants. Therefore, adding betaine (50 $\mathrm{mm}$ ) under RDI promotes lettuce plant growth and yield, and it can be used for the rapid monitoring and early detection of water stress injury in the seedling stage and screening of individual plants that exhibit tolerance to water stress.

There were significant differences in net photosynthesis and WUE values for the main and interaction effects, except for transpiration in the $\mathrm{B}$ effect and $\mathrm{WUE}_{\mathrm{i}}$ in the I $\times$ B effect (Table 2). There were no marked differences in transpiration (1.03-1.17 $\left.\mathrm{mmol} \cdot \mathrm{m}^{-2} \cdot \mathrm{s}^{-1} \mathrm{H}_{2} \mathrm{O}\right)$ and $\mathrm{WUE}_{\mathrm{i}}(10.34-12.85$ mmol $\mathrm{CO}_{2} / \mathrm{mol} \mathrm{H}_{2} \mathrm{O}$ ) after 4 weeks under FI.
However, under RDI, all 50-mm and 100-mm betaine treatments displayed significantly higher transpiration $\left(0.74\right.$ and $\left.0.92 \mathrm{mmol} \cdot \mathrm{m}^{-2} \cdot \mathrm{s}^{-1} \mathrm{H}_{2} \mathrm{O}\right)$ and net photosynthesis $(9.42$ and 10.89 $\mu \mathrm{mol} \cdot \mathrm{m}^{-2} \cdot \mathrm{s}^{-1} \mathrm{CO}_{2}$ ) values compared with controls $\left(0.31\right.$ and $\left.6.80 \mu \mathrm{mol} \cdot \mathrm{m}^{-2} \cdot \mathrm{s}^{-1} \mathrm{CO}_{2}\right)$. It is noteworthy that significantly higher $\mathrm{WUE}_{\text {yield }}$ $\left(63.68\right.$ and $\left.64.87 \mathrm{~kg} \cdot \mathrm{m}^{-3}\right)$ and WUE $\mathrm{Wiomass}_{\text {bi }}(4.43$ and $4.57 \mathrm{~g} \cdot \mathrm{km}^{-3}$ ) values were detected in betaine treatments under RDI compared with other treatments.

Water performs various functions in plants, including structural support through turgor pressure and as an electron donor in photosynthesis. Its absence has a direct impact on plant production, mainly due to disarrangements in most photosynthetic components. Therefore, the ability of plants to withstand such stress is of utmost importance for agribusiness in any country, and especially in major crops such as lettuce. Water stress is a predominant factor in determining the global geographic distribution of natural vegetation and agricultural crop yields; however, the effective management of cropping systems and irrigation water in the face of limited water resources will pivotally depend on our ability to maximize crop water use rather than simply maximizing yields. The total amount of water applied to lettuce in 4 weeks under FI was 995 to $1140 \mathrm{~cm}^{3}$.
Compared with this amount, RDI received remarkably less irrigation water, ranging from 495 to $660 \mathrm{~cm}^{3}$. Total water irrigation decreased under RDI, indicating that lettuce suffered from water stress injury. Betaine was applied two times after planting, and because betaine application to RDI-treated plants improved plant water status, it is reasonable to expect that this in turn led to favorable effects on photosynthesis parameters and WUE values. This implies that betaine treatment increased yield-related traits, photosynthesis parameters, and WUE values under RDI and boosted water stress tolerance.

Deficit irrigation is correctly applied only through an understanding of the yield response to water. The capacity of plants to absorb nutrients is typically weak when antitranspirants are sprayed onto leaves under water-deficit conditions because of the resulting limited transpiration flux (Amor et al., 2010). Osmoregulators (i.e., betaine) are accumulated in plants as versatile instruments to ecological stress, and the foliar application of betaine alleviates drought and salt stress-induced growth inhibition in rice (Wutipraditkul et al., 2015), maize (Hamid and Armin, 2013), pepper (Korkmaz et al., 2015), barley (Wang et al., 2019), cowpea (Manaf, 2016), and cucumber (Estaji et al., 

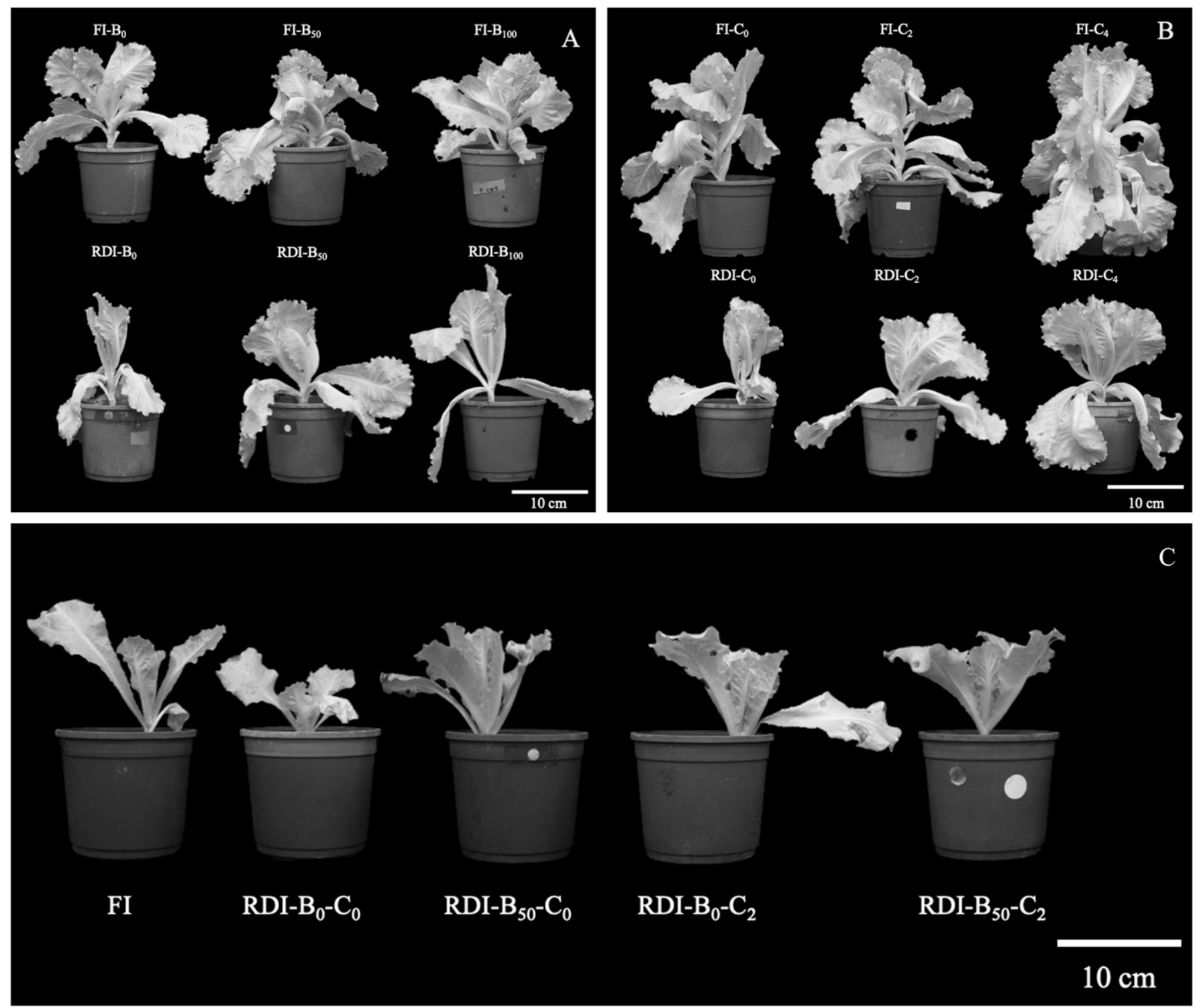

Fig. 1. Effects of different concentrations of betaine (A), chitin $(\mathbf{B})$, and betaine and chitin $(\mathbf{C})$ on the morphological appearance of lettuce plants under full irrigation (FI) and regulated deficit irrigation (RDI). Betaine $(0,50$, and $100 \mathrm{~mm} /$ plant) was foliar-treated and chitin $(0,2$, and $4 \mathrm{~g} / \mathrm{kg})$ was applied directly to the soil. Bar indicates $10 \mathrm{~cm}$.

2019). Furthermore, betaine-treated leaves significantly increase the ability of the antioxidant defense system to resist abiotic stresses in different plant species (Osman, 2015; Shams et al., 2016; Yao et al., 2018). Tomato plants could be produced under sandy soil conditions using RDI strategy at transpiration with foliar spraying by betaine to overcome the negative effects of water stress and improve the vegetative growth, fruit yield, and quality (Ragab et al., 2015). Betaine altered hormone levels and antioxidant activity to maintain membrane stability and photosynthetic capability to improve winter wheat WUE and grain yield under RDI conditions (Ahmed et al., 2019). When we applied $50 \mathrm{~mm}$ betaine under RDI in this study, plants increased their transpiration capacity without affecting aboveground growth. It is not clear how betaine treatment improves the water status of leaves during water stress, but it might be that water uptake efficiency is improved or that water loss is retarded, or both.

Comparisons between chitin-treated and -untreated plants subjected to FI and RDI conditions. Tables 3 and 4 present the effects of chitin treatments on yield components, gas exchange parameters, and WUE values of lettuce under FI and RDI. All measured traits appeared to differ significantly in all effects, except that the $\mathrm{I} \times \mathrm{C}$ effect did not significantly affect LA (Table 3) and net photosynthesis (Table 4). There was an increased trend in all measured traits in all plants when chitin application increased from 0 to $4 \mathrm{~g} / \mathrm{kg}$ under FI (Table 3). However, compared with the no-chitin treatment, when we applied 2 and 4 $\mathrm{g} / \mathrm{kg}$ of chitin under RDI, each pot exhibited significantly higher levels in all measured traits except plant height. After treatment with $2 \mathrm{~g} / \mathrm{kg}$ of chitin to plants under RDI, LA $\left(877.46 \mathrm{~cm}^{2}\right)$ was significantly increased by $25.6 \%$ compared with the control ( 480.30 $\left.\mathrm{cm}^{2}\right)$. Moreover, chitin treatment $(2 \mathrm{~g} / \mathrm{kg})$ showed a clearly protective effect in RDI plants, enhancing their total fresh weight by $75 \%(41.11 \mathrm{~g} /$ plant $)$ in comparison with untreated plants $(23.49 \mathrm{~g} /$ plant$)$. The total amount of water applied under FI and RDI was 990 to $1085 \mathrm{~mL}$ and 560 to $715 \mathrm{~mL}$, respectively. There were significant differences in transpiration, photosynthesis, and WUE values among chitin applications (2 and $4 \mathrm{~g} / \mathrm{kg}$ ), showing significantly higher measured values under all irrigation conditions except transpiration under FI (1.13 $\left.\mathrm{mmol} \cdot \mathrm{m}^{-2} \cdot \mathrm{s}^{-1} \mathrm{H}_{2} \mathrm{O}\right)$ and $\mathrm{WUE}_{\mathrm{i}}$ under RDI (14.12 $\left.\mu \mathrm{mol} \mathrm{CO} 2 / \mathrm{mmol} \mathrm{H}_{2} \mathrm{O}\right)$, in comparison with controls (Table 4 ).

We also assessed the effect of chitin treatment on plant growth under RDI. Figure 1B depicts serious epinasty and senescence in the outer leaves of chitinuntreated plants under RDI after 4 weeks of stress; however, most leaves looked green 
Table 3. Effects of different concentrations of chitin on the yield performance of lettuce under full irrigation (FI) and regulated deficit irrigation (RDI).

\begin{tabular}{|c|c|c|c|c|c|c|c|c|c|}
\hline \multirow{2}{*}{$\begin{array}{l}\text { Irrigation } \\
\text { treatment }\end{array}$} & \multirow{2}{*}{$\begin{array}{c}\text { Chitin } \\
\text { concn }(\mathrm{g} / \mathrm{kg})\end{array}$} & \multicolumn{2}{|c|}{ Plant ht (cm) } & \multirow{2}{*}{$\begin{array}{l}\text { Leaf area } \\
\left(\mathrm{cm}^{2}\right)\end{array}$} & \multicolumn{3}{|c|}{ Fresh wt (g/plant) } & \multirow{2}{*}{$\begin{array}{c}\text { Total dry } \\
\text { wt (g/plant) }\end{array}$} & \multirow{2}{*}{$\begin{array}{l}\text { Total water } \\
\text { irrigation }\left(\mathrm{cm}^{3}\right.\end{array}$} \\
\hline & & 0 weeks & 4 weeks & & Shoot & Root & Total & & \\
\hline FI & 2 & $12.17 \mathrm{a}$ & $22.18 \mathrm{a}$ & $995.79 \mathrm{~b}$ & $45.43 \mathrm{~b}$ & $4.34 \mathrm{a}$ & $49.76 \mathrm{~b}$ & $3.15 \mathrm{a}$ & 1020 \\
\hline FI & 4 & $11.73 \mathrm{a}$ & $22.57 \mathrm{a}$ & $1173.33 \mathrm{a}$ & $56.59 \mathrm{a}$ & $4.55 \mathrm{a}$ & $61.14 \mathrm{a}$ & $3.41 \mathrm{a}$ & 990 \\
\hline RDI & 2 & $11.57 \mathrm{a}$ & $20.35 \mathrm{~b}$ & $877.46 \mathrm{bc}$ & $36.33 \mathrm{c}$ & $4.78 \mathrm{a}$ & $41.11 \mathrm{c}$ & $2.35 \mathrm{~b}$ & 560 \\
\hline RDI & 4 & $11.00 \mathrm{a}$ & $19.92 \mathrm{~b}$ & $830.48 \mathrm{c}$ & $35.09 \mathrm{c}$ & $3.82 \mathrm{~b}$ & $38.91 \mathrm{~cd}$ & $2.77 \mathrm{~b}$ & 565 \\
\hline \multicolumn{10}{|c|}{ Source of variation } \\
\hline \multicolumn{2}{|c|}{$\mathrm{I} \times \mathrm{C}$} & & $*$ & NS & * & * & ** & $*$ & $*$ \\
\hline
\end{tabular}

Data were recorded and calculated after 4 weeks of irrigation and chitin treatments from six replicates. Means in the same column within treatments followed by different letters are significantly different at $P \leq 0.05$ by least significant difference. Each treatment is assumed to be dependent on the other. Analysis of variance results of the main effects of irrigation (I), chitin (C), and their interaction effect (I $\times \mathrm{C})$ on agronomic performance of lettuce are shown as NS, *,**, and *** as nonsignificant or significant at $P \leq 0.05,0.01$, or 0.001 , respectively.

Table 4. Effects of different concentrations of chitin on the gas exchange parameters and water use efficiency (WUE , $_{\mathrm{i}} \mathrm{WUE}_{\mathrm{yield}}, \mathrm{WUE}_{\text {biomass }}$ ) of lettuce under full irrigation (FI) and regulated deficit irrigation (RDI).

\begin{tabular}{|c|c|c|c|c|c|c|c|c|c|}
\hline \multirow[b]{2}{*}{$\begin{array}{l}\text { Irrigation } \\
\text { treatment }\end{array}$} & \multirow[b]{2}{*}{$\begin{array}{c}\text { Chitin } \\
\text { concn }(\mathrm{g} / \mathrm{kg})\end{array}$} & \multicolumn{2}{|c|}{0 weeks } & \multicolumn{2}{|c|}{4 weeks } & \multirow[b]{2}{*}{$\begin{array}{c}\text { Net photosynthesis } \\
\left(\mu \mathrm{mol} \cdot \mathrm{m}^{-2} .\right. \\
\left.\mathrm{s}^{-1} \mathrm{CO}_{2}\right)\end{array}$} & \multirow[b]{2}{*}{$\begin{array}{c}\text { WUEi }(\mu \mathrm{mol} \\
\mathrm{CO}_{2} / \mathrm{mmol} \\
\left.\mathrm{H}_{2} \mathrm{O}\right)\end{array}$} & \multirow[b]{2}{*}{$\begin{array}{l}\text { WUE }_{\text {yield }} \\
\left(\mathrm{kg} \cdot \mathrm{m}^{-3}\right)\end{array}$} & \multirow[b]{2}{*}{$\begin{array}{c}\text { WUE }_{\text {biomass }} \\
\left(\mathrm{kg} \cdot \mathrm{m}^{-3}\right)\end{array}$} \\
\hline & & $\begin{array}{c}\text { Transpiration } \\
\left(\mathrm{mmol} \cdot \mathrm{m}^{-2} .\right. \\
\left.\mathrm{s}^{-1} \mathrm{H}_{2} \mathrm{O}\right)\end{array}$ & $\begin{array}{c}\text { Net photosynthesis } \\
\left(\mu \mathrm{mol} \cdot \mathrm{m}^{-2} .\right. \\
\left.\mathrm{s}^{-1} \mathrm{CO}_{2}\right)\end{array}$ & $\begin{array}{c}\mathrm{WUE}_{\mathrm{i}}(\mu \mathrm{mol} \\
\mathrm{CO}_{2} / \mathrm{mmol} \\
\left.\mathrm{H}_{2} \mathrm{O}\right)\end{array}$ & $\begin{array}{c}\text { Transpiration } \\
\left(\mathrm{mmol} \cdot \mathrm{m}^{-2} \text {. }\right. \\
\left.\mathrm{s}^{-1} \mathrm{H}_{2} \mathrm{O}\right)\end{array}$ & & & & \\
\hline$\overline{\text { FI }}$ & 0 & $0.97 \mathrm{a}$ & $11.08 \mathrm{a}$ & $12.75 \mathrm{a}$ & $1.13 \mathrm{a}$ & $10.36 \mathrm{~b}$ & $8.70 \mathrm{c}$ & $31.32 \mathrm{~d}$ & $2.13 \mathrm{c}$ \\
\hline FI & 4 & $1.04 \mathrm{a}$ & $10.00 \mathrm{a}$ & $9.99 \mathrm{a}$ & $1.22 \mathrm{ab}$ & $14.07 \mathrm{a}$ & $12.86 \mathrm{~b}$ & $61.75 \mathrm{~b}$ & $3.44 \mathrm{~b}$ \\
\hline RDI & 0 & $0.94 \mathrm{a}$ & $10.81 \mathrm{a}$ & $13.22 \mathrm{a}$ & $0.44 \mathrm{c}$ & $5.66 \mathrm{c}$ & $14.12 \mathrm{a}$ & $34.25 \mathrm{~d}$ & $2.52 \mathrm{c}$ \\
\hline RDI & 2 & $1.03 \mathrm{a}$ & $10.75 \mathrm{a}$ & $10.98 \mathrm{a}$ & $1.07 \mathrm{ab}$ & $9.66 \mathrm{~b}$ & $9.12 \mathrm{c}$ & $73.40 \mathrm{a}$ & $4.30 \mathrm{a}$ \\
\hline Irrigation & atment (I) & & & & $* * *$ & $* * *$ & $*$ & $* * *$ & $* *$ \\
\hline Chitin con & ntration (C) & & & & $* *$ & $* *$ & * & $* *$ & $*$ \\
\hline $\mathrm{I} \times \mathrm{C}$ & & & & & $* * *$ & NS & * & $*$ & * \\
\hline
\end{tabular}

Data were recorded and calculated after 4 weeks of irrigation and betaine treatments from six replicates. Means in the same column within treatments followed by different letters are significantly different at $P \leq 0.05$ by least significant difference. Each treatment is assumed to be dependent on the other. Analysis of variance results of the main effects of irrigation $(\mathrm{I})$, chitin $(\mathrm{C})$, and their interaction effect $(\mathrm{I} \times \mathrm{C})$ on gas exchange parameters and WUE values of lettuce are shown as Ns, *, **, and $* * *$ as nonsignificant or significant at $P \leq 0.05,0.01$, or 0.001 , respectively.

and healthy under chitin applications and RDI conditions. In addition, there was a gradual inhibition in growth over time under RDI without chitin treatments. These observations demonstrated that plants were highly regulated by chitin and all measured traits (except plant height) drastically elevated; thus, treating lettuce with chitin can mitigate the effects of water stress. Water stress had a harmful effect during RDI, the degree of chlorosis being related to a reduction in LA values. Chitin application might reduce or delay water stress, thereby allowing plants to survive and function during stress. This ability perhaps can be attributed to an avoidance of water stress, as indicated by the higher yield components, photosynthesis parameters, and WUE values in chitin-treated plants compared with chitin-untreated plants during RDI conditions. It is also possible that chitin absorbs soil moisture, thus increasing the water-holding capacity of the soil and, consequently, more water being available for plant use (Yu et al., 2011).

Chitin features prominent biochemical similarities in plant cell walls, including neutrally charged linear polysaccharide chains that provide mechanical, physical, and structural stability (Kurita, 2006). Chitin treatment alleviates drought stress and increases plant growth with the production of stress protective metabolites in white clover
(Li et al., 2017) and sweet basil (Pirbalouti et al., 2017). Moreover, Bittelli et al. (2001) reported that the foliar application of chitin decreased transpiration in pepper plants and reduced water use while maintaining biomass production and yield. Water stress decreases photosynthesis parameters in maize, but the application of chitin and derivatives increases them (dos Reis et al., 2019). The application of a mixture of chitin derivatives also induces a tolerance to water deficit in maize, improving the antioxidant system and increasing photosynthesis and grain yield (Rabêlo et al., 2019). Chitin has the same effects of salt stress on plants by increasing the key enzymes related to the closure of cucumber stomata, resulting in the reduction of water loss (Song et al., 2006). To date, no studies have been conducted on the effects of chitin treatment on the yield, photosynthesis, and WUE values of lettuce under RDI. Our results demonstrate that RDI affected lettuce yield components, net photosynthesis, and WUE values. In general, plants with higher net photosynthesis and WUE values also had higher total fresh weight and dry weight in the chitin-treated groups, implying that individual plants manifest yield indicators and exhibit greater photosynthesis and WUE. Because of the low cost of chitin available as a shellfish waste from seafood processing, improvements in these parameters under RDI conditions will reduce the cost per plant or per acre of new plantings.

Effects of betaine and chitin treatments on plant physiology and morphology under FI and $R D I$. Expt. 3 combined optimized treatments based on Expts. 1 and 2 to test the efficacy of betaine and chitin applications for improving lettuce plant growth by enhancing the tolerance of plants to water stress. We used $50 \mathrm{~mm}$ betaine (foliar application) and chitin $2 \mathrm{~g} / \mathrm{kg}$ (soil solution) alone or in combination in Expt. 3. The synergistic effects of irrigation and chemical treatments on those measurements were analyzed by a three-factor completely randomized ANOVA, and each treatment was assumed to be dependent on the other. Side-by-side comparisons on the impact of chitin and betaine on the yield traits, gas exchange parameters, and WUE values of lettuce under FI and RDI conditions are summarized in Tables 5 and 6 . All of the measurements appeared to significantly differ in terms of the main effects (I, B, and $\mathrm{C}$ ), except for $\mathrm{WUE}_{\mathrm{i}}, \mathrm{WUE}_{\mathrm{yiel}}$, and WUE $_{\text {biomass }}$ in $\mathrm{B}$ and $\mathrm{C}$ effects. Moreover, only those horticultural traits showed significant differences in terms of the interaction effect $(\mathrm{I} \times \mathrm{C})$. Thus, the measured traits of the plants responded differently to betaine and chitin treatments alone or mixtures under FI and RDI

Compared with no chemical treatment, the application of betaine $(50 \mathrm{~mm})$ or chitin 
Table 5. Effects of different concentrations of betaine and chitin on the yield performance of lettuce under full irrigation (FI) and regulated deficit irrigation (RDI).

\begin{tabular}{|c|c|c|c|c|c|c|c|c|c|c|}
\hline \multirow{2}{*}{$\begin{array}{l}\text { Irrigation } \\
\text { treatment }\end{array}$} & \multirow{2}{*}{$\begin{array}{l}\text { Betaine } \\
\text { (mM) }\end{array}$} & \multirow{2}{*}{$\begin{array}{l}\text { Chitin } \\
(\mathrm{g} / \mathrm{kg})\end{array}$} & \multicolumn{2}{|c|}{ Plant ht (cm) } & \multirow{2}{*}{$\begin{array}{l}\text { Leaf area } \\
\left(\mathrm{cm}^{2}\right)\end{array}$} & \multicolumn{3}{|c|}{ Fresh wt (g/plant) } & \multirow{2}{*}{$\begin{array}{l}\text { Total dry wt } \\
\text { (g/plant) }\end{array}$} & \multirow{2}{*}{$\begin{array}{c}\text { Total water } \\
\text { irrigation }\left(\mathrm{cm}^{3}\right.\end{array}$} \\
\hline & & & 0 week & 4 weeks & & Shoot & Root & Total & & \\
\hline RDI & 0 & 0 & $10.76 \mathrm{a}$ & $10.57 \mathrm{c}$ & $68.53 \mathrm{c}$ & $2.68 \mathrm{c}$ & $0.21 \mathrm{~d}$ & $2.89 \mathrm{~d}$ & $0 \mathrm{c}$ & 625 \\
\hline RDI & 50 & 0 & $10.72 \mathrm{a}$ & $14.23 \mathrm{a}$ & $204.07 \mathrm{a}$ & $8.26 \mathrm{a}$ & $0.58 \mathrm{~b}$ & $8.84 \mathrm{~b}$ & $1.32 \mathrm{a}$ & 475 \\
\hline RDI & 50 & 2 & $10.82 \mathrm{a}$ & $14.30 \mathrm{a}$ & $218.43 \mathrm{a}$ & $8.10 \mathrm{a}$ & $0.87 \mathrm{a}$ & $8.97 \mathrm{~b}$ & $1.45 \mathrm{a}$ & 500 \\
\hline \multicolumn{11}{|c|}{ Source of variation } \\
\hline \multicolumn{3}{|c|}{ Irrigation treatment (I) } & & $* *$ & $* *$ & ** & ** & ** & * & \\
\hline \multicolumn{3}{|c|}{$\mathrm{B} \times \mathrm{C}$} & & *** & $* * *$ & $* * *$ & ** & $* * *$ & ** & \\
\hline
\end{tabular}

Data were recorded and calculated after 4 weeks of irrigation and chemical treatments from six replicates. Means in the same column within treatments followed by different letters are significantly different at $P \leq 0.05$ by least significant difference. Each treatment is assumed to be dependent on the other. Analysis of variance results of the main effects of irrigation (I), betaine $(B)$, chitin $(C)$, and their interaction effect $(B \times C)$ on the agronomic performance of lettuce are shown as *,*, and *** as significant at $P \leq 0.05,0.01$, or 0.001 , respectively.

Table 6. Effects of different concentrations of betaine and chitin on the gas exchange parameters and water use efficiency (WUE $\left.\mathrm{W}_{\mathrm{i}}, \mathrm{WUE}_{\mathrm{yield}}, \mathrm{WUE}_{\mathrm{biomass}}\right)$ of lettuce under full irrigation (FI) and regulated deficit irrigation (RDI).

\begin{tabular}{|c|c|c|c|c|c|c|c|c|c|c|}
\hline \multirow[b]{2}{*}{$\begin{array}{l}\text { Irrigation } \\
\text { treatment }\end{array}$} & \multirow[b]{2}{*}{$\begin{array}{l}\text { Chitin } \\
\text { (mM) }\end{array}$} & \multirow[b]{2}{*}{$\begin{array}{c}\text { Betaine } \\
(\mathrm{g} / \mathrm{kg})\end{array}$} & \multicolumn{2}{|c|}{0 weeks } & \multicolumn{2}{|c|}{4 weeks } & \multirow[b]{2}{*}{$\begin{array}{l}\text { Net photosynthesis } \\
\left(\mu \mathrm{mol} \cdot \mathrm{m}^{-2} \cdot \mathrm{s}^{-1} \mathrm{CO}_{2}\right)\end{array}$} & \multirow[b]{2}{*}{$\begin{array}{c}\text { WUE }_{\mathrm{i}} \\
\left(\mu \mathrm{mol} \mathrm{CO} \mathrm{C}_{2} /\right. \\
\left.\mathrm{mmol} \mathrm{H}_{2} \mathrm{O}\right)\end{array}$} & \multirow[b]{2}{*}{$\begin{array}{l}\text { WUE } \text { yield } \\
\left(\mathrm{kg} \cdot \mathrm{m}^{-3}\right)\end{array}$} & \multirow[b]{2}{*}{$\begin{array}{c}\text { WUE }_{\text {biomass }} \\
\left(\mathrm{kg} \cdot \mathrm{m}^{-3}\right)\end{array}$} \\
\hline & & & $\begin{array}{c}\text { Transpiration } \\
\left(\mathrm{mmol} \cdot \mathrm{m}^{-2} \cdot \mathrm{s}^{-1}\right. \\
\left.\mathrm{H}_{2} \mathrm{O}\right)\end{array}$ & $\begin{array}{c}\text { Net photosynthesis } \\
\left(\mu \mathrm{mol} \cdot \mathrm{m}^{-2} \cdot \mathrm{s}^{-1}\right. \\
\left.\mathrm{CO}_{2}\right)\end{array}$ & $\begin{array}{c}\mathrm{WUE}_{\mathrm{i}}\left(\mu \mathrm{mol} \mathrm{CO} \mathrm{CO}_{2} /\right. \\
\left.\mathrm{mmol} \mathrm{H}_{2} \mathrm{O}\right)\end{array}$ & $\begin{array}{c}\text { Transpiration } \\
\left(\mathrm{mmol} \cdot \mathrm{m}^{-2} \cdot \mathrm{s}^{-1}\right. \\
\left.\mathrm{H}_{2} \mathrm{O}\right)\end{array}$ & & & & \\
\hline$\overline{\text { FI }}$ & 0 & 0 & $1.10 \mathrm{a}$ & $7.68 \mathrm{a}$ & $7.25 \mathrm{a}$ & $1.09 \mathrm{a}$ & $4.76 \mathrm{c}$ & $4.61 \mathrm{c}$ & $5.02 \mathrm{~b}$ & $0.91 \mathrm{~b}$ \\
\hline RDI & 50 & 0 & $1.04 \mathrm{a}$ & $7.98 \mathrm{a}$ & $7.92 \mathrm{a}$ & $0.79 \mathrm{~b}$ & $5.01 \mathrm{~b}$ & $6.71 \mathrm{~b}$ & $18.60 \mathrm{a}$ & $2.77 \mathrm{a}$ \\
\hline RDI & 0 & 2 & $1.01 \mathrm{a}$ & $8.43 \mathrm{a}$ & $8.44 \mathrm{a}$ & $0.80 \mathrm{~b}$ & $5.66 \mathrm{~b}$ & $6.81 \mathrm{~b}$ & $17.64 \mathrm{a}$ & $2.60 \mathrm{a}$ \\
\hline RDI & 50 & 2 & $1.01 \mathrm{a}$ & $7.70 \mathrm{a}$ & $9.07 \mathrm{a}$ & $1.01 \mathrm{a}$ & $6.45 \mathrm{a}$ & $6.93 \mathrm{~b}$ & $17.94 \mathrm{a}$ & $2.91 \mathrm{a}$ \\
\hline \multicolumn{3}{|c|}{ Chitin concentration (C) } & & & & * & ** & NS & NS & NS \\
\hline \multicolumn{3}{|c|}{$\mathrm{B} \times \mathrm{C}$} & & & & NS & NS & NS & NS & NS \\
\hline
\end{tabular}

Data were recorded and calculated after 4 weeks of irrigation and chemical treatments from six replicates. Means in the same column within treatments followed by different letters are significantly different at $P \leq 0.05$ by least significant difference. Each treatment is assumed to be dependent on the other. Analysis of variance results of the main effects of irrigation $(\mathrm{I})$, betaine $(\mathrm{B})$, chitin $(\mathrm{C})$, and their interaction effect $(\mathrm{B} \times \mathrm{C})$ on gas exchange parameters and WUE values of lettuce are shown as Ns, *, and ** as nonsignificant or significant at $P \leq 0.05$ or 0.01 , respectively.

$(2 \mathrm{~g} / \mathrm{kg})$ alone and combined to plants under RDI had significantly higher measured values, except for transpiration (1.09 $\left.\mathrm{mmol} \cdot \mathrm{m}^{-2} \cdot \mathrm{s}^{-1} \mathrm{H}_{2} \mathrm{O}\right)$ and $\mathrm{WUE}_{\mathrm{i}}(8.15 \mu \mathrm{mol}$ $\mathrm{CO}_{2} / \mathrm{mmol} \mathrm{H}_{2} \mathrm{O}$ ). Moreover, chitin and betaine combined treatment under RDI did not produce significantly higher measured values than those plants treated by chitin and betaine alone under RDI, except for transpiration $\left(1.01 \mathrm{mmol} \cdot \mathrm{m}^{-2} \cdot \mathrm{s}^{-1} \mathrm{H}_{2} \mathrm{O}\right)$ and net photosynthesis $\left(6.45 \mathrm{mmol} \cdot \mathrm{m}^{-2} \cdot \mathrm{s}^{-1}\right.$ $\left.\mathrm{H}_{2} \mathrm{O}\right)$. Compared with FI $\left(1095 \mathrm{~cm}^{3}\right)$, RDI plants received remarkably less irrigation water, ranging from 475 to $625 \mathrm{~cm}^{3}$. Figure $1 \mathrm{C}$ illustrates that chlorosis and dwarfing in most RDI and chemicaluntreated plants was visibly greater than in chemical-treated plants subjected to RDI. These results reveal that treatment with a combination of betaine and chitin did not exhibit a synergistic optimum on yield and WUE values under RDI. Different biostimulants acted differently under RDI treatment; however, each biostimulant is not necessarily equally significant in protecting against water stress. The impacts of changing plant physiology and morphology on water stress tolerance and plant health were affected by betaine and chitin application. Using chitin or betaine alone on plants under RDI significantly increased yield-related traits and $\mathrm{WUE}_{\text {yield }}$ and $\mathrm{WUE}_{\text {biomass }}$ values in lettuce compared with controls, and thus can be applied on a commercial scale for saving water without sacrificing yield.

Water availability is becoming the most critical limiting factor for crop production, and this fact has increased the emphasis that policymakers are placing on both demand and supply options for water management. There is limited information available regarding the physiological development of these plants grown under water stress. The induced water stress tolerance response can be directly linked to the coordinated response of biostimulants to effectively alleviate the inhibitory effects of water stress. Knowledge of water stress-responsive biostimulants is critical for enabling the further understanding of irrigation timing in water stress tolerance. Our results can be used to improve the water stress tolerance of this crop and to develop management practices for field cultivation and enhance cultivation when water resources are limited. In addition, better understanding of the growing characteristics of these plants also would aid in their effective cultivation on arid lands or in extreme climates. Increasing yield and WUE from different biostimulants under RDI provided plants with increased water stress tolerance, playing a key role in providing better adaptation to water stress. The effects of water stress on lettuce can be reduced by treatment with betaine and chitin alone, because these chemicals may protect cell membranes from the adverse effects of water stress. Betaine and chitin act at a convergence point for integrating different signals, minimize cell damage caused by water deficits, and improve the physiological and biochemical condition of plants, thus making plants more tolerant to aridity.

\section{Conclusions}

We studied the effects of optimal concentrations of betaine and chitin treatments on the changes in yield and WUE in lettuce under RDI conditions. Biostimulant treatment with betaine and chitin increased the tolerance of lettuce to water stress by exhibiting markedly higher yield-related traits, gas exchange parameters, and WUE values under RDI than control plants. Compared with the mixture treatment and controls, treatments with either $2 \mathrm{~g} / \mathrm{kg}$ chitin or $50 \mathrm{~mm}$ betaine alone improve water stress and can be used as a substitute technology for developing WUE plants and improving plant yields, resulting in increased farm income. These findings may have greater significance for farming in dry lands and offer information for further physiological studies on lettuce WUE and water stress tolerance. Further studies are needed to confirm the specific signal regulation and transduction components or identify 
water-stressed responsive genes and proteins that are present in chitin- or betaine-mediated improvements of water stress tolerance in lettuce through genetic modification or mutagenesis, and provide better usage of betaine and chitin in water stress management.

\section{Literature Cited}

Ahmed, N., Y. Zhang, K. Li, Y. Zhou, M. Zhang, and Z. Li. 2019. Exogenous application of glycine betaine improved water use efficiency in winter wheat (Triticum aestivum L.) via modulating photosynthetic efficiency and antioxidative capacity under conventional and limited irrigation conditions. Crop J., doi: 10. 1016/j.cj.2019.03.004.

Ahmad, R., C.J. Lim, and S. Kwon. 2013. Glycine betaine: A versatile compound with great potential for gene pyramiding to improve crop plant performance against environmental stresses. Plant Biotechnol. Rep. 7:49-57.

Amor, F.M.D., P. Cuadra-Crespo, D.J. Walker, J.M. Camara, and R. Madrid. 2010. Effect of foliar application of antitranspirant on photosynthesis and water relations of pepper plants under different levels of $\mathrm{CO}_{2}$, and water stress. J. Plant Physiol. 167:1232-1238.

Bittelli, M., M. Flury, G.S. Campbell, and E.J. Nichols. 2001. Reduction of transpiration through foliar application of chitosan. Agr. For. Meteorol. 107:167-175.

Calvo, P., L. Nelson, and J.W. Kloepper. 2014. Agricultural uses of plant biostimulants. Plant Soil 383:31-41.

Chai, Q., Y. Gan, C. Zhai, H.L. Xu, R.M. Waskom, and Y. Niu. 2016. Regulated deficit irrigation for crop production under drought stress. A review. Agron. Sustain. Dev. 36:3.

De Pascale, S., L. D. Costa, S. Vallone, G. Barbieri, and A. Maggio. 2011. Increasing water use efficiency in vegetable crop production: From plant to irrigation systems efficiency. HortTechnology 21:301-308.

dos Reis, C.O., P.C. Magalhaes, G. Roniel, A. Lorena, M.R. Valquiria, and T.C. Diogo. 2019. Action of N-succinyl and N,O-dicarboxymethyl chitosan derivatives on chlorophyll photosynthesis and fluorescence in drought-sensitive maize. J. Plant Growth Regul. 38:619-630.

du Jardin, P. 2015. Plant biostimulants: Definition, concept, main categories and regulation. Scientia Hort. 196:3-14.

Estaji, A., H.M. Kalaji, H.R. Karimi, H.R. Roosta, and S.M. Moosavi-Nezhad. 2019. How glycine betaine induces tolerance of cucumber plants to salinity stress? Photosynth. 57(3):753-761.

Fereres, E., D.A. Goldhamer, and V.O. Sadras. 2012. Yield response to water of fruit trees and vines: Guidelines, p. 246-295. In: P. Steduto, T.C. Hsiao, E. Fereres, and D. Raes (eds.). Crop yield response to water irrigation and drainage paper. 2nd ed. FAO, Rome, Italy.

Galindo, A., J. Collado-Gonzalez, I. Grinan, M. Corell, A. Centeno, and M.J. Martin-Palomo. 2018. Deficit irrigation and emerging fruit crops as a strategy to save water in Mediterranean semiarid agrosystems. Agr. Water Manage. 202:311-324.

Garces-Restrepo, C. and M. Giovanni. 2008. Irrigation management transfer: Worldwide efforts and results. FAO Water Reports, Rome, 32.

Hamid, R.M. and M. Armin. 2013. The interaction effect of drought and exogenous application of glycine betaine on corn (Zea mays L.). Eur. J. Exp. Biol. 3:197-206.

Hidangmayum, A., D. Padmanabh, K. Deepmala, and H. Akhouri. 2019. Application of chitosan on plant responses with special reference to abiotic stress. Physiol. Mol. Biol. Plants 25: 313-326.

Jiménez-Arias, D., J. Francisco, B. GarcíaMachadoa, J.C. Morales-Sierraa, E. Luisb, M. Suarezb, F. Hernándeza, F. Valdésb, and A.B. Andrés. 2019. Lettuce plants treated with L-pyroglutamic acid increase yield under water deficit stress. Environ. Exp. Bot. 158:215-222.

Korkmaz, A., O. Deger, and F. Kocacinar. 2015. Alleviation of water stress effects on pepper seedlings by foliar application of glycine betaine. N. Z. J. Crop Hort. Sci. 43:18-31.

Kurita, K. 2006. Chitin and chitosan: Functional biopolymers from marine crustaceans. Mar. Biotechnol. (NY) 8:203-226.

Li, Z., Y. Zhang, X. Zhan, E. Merewitz, Y. Peng, X. Ma, and Y. Yan. 2017. Metabolic pathways regulated by chitosan contributing to drought resistance in white clover. J. Proteome Res. 16:3039-3052.

Malcom, S., E. Marshall, M. Aillery, P. Heisey, M. Livingston, and K. Rubenstein. 2012. Agricultural adaptation to a changing climate: Economic and environmental implications vary by U.S region. USDA Economic Res. Service. Economic Res. Rep. No. 136.

Malejane, D.N., P. Tinyani, P. Soundy, Y. Sultanbawa, and D. Sivakumar. 2018. Deficit irrigation improves phenolic content and antioxidant activity in leafy lettuce varieties. Food Sci. Nutr. 6:334-341.

Manaf, H.H. 2016. Beneficial effects of exogenous selenium, glycinebetaine and seaweed extract on salt stressed cowpea plant. Ann. Agr. Sci. 61(1):41-48.

Marsal, J., J. Casadesus, G. Lopez, M. Mata, J. Bellvert, and J. Girona. 2016. Sustainability of regulated deficit irrigation in a mid-maturing peach cultivar. Irr. Sci. 34:201-208.

Osman, H. 2015. Enhancing antioxidant-yield relationship of peaplant under drought at different growth stages by exogenously applied glycine betaine and proline. Ann. Agr. Sci. 60(2):389-402.

Patrick, D.J. 2015. Plant biostimulants: Definition, concept, main categories and regulation. Scientia Hort. 196:3-14.

Pirbalouti, A.G., F. Malekpoor, A. Salimi, and A. Golparvar. 2017. Exogenous application of chitosan on biochemical and physiological characteristics, phenolic content and antioxidant activity of two species of basil (Ocimum ciliatum and Ocimum basilicum) under reduced irrigation. Scientia Hort. 217:114-122.

Pruszyński, S. 2008. Place biostimulators in crop protection and fertilization. Wieś Jutra 5:2325.

Rabêlo, V.M., P.C. Magalhães, L.A. Bressanin, and D.T. Carvalho. 2019. The foliar application of a mixture of semisynthetic chitosan derivatives induces tolerance to water deficit in maize, improving the antioxidant system and increasing photosynthesis and grain yield. Sci. Rep. 9:8164.

Rady, M.O.A., W.M. Semida, T.A. Abd ElMageed, K.A. Hemid, and M.M. Rady. 2018. Up-regulation of antioxidative defense systems by glycine betaine foliar application in onion plants confer tolerance to salinity stress. Scientia Hort. 240:614-622.
Ragab, M.E., A.S. Nesreen, O.M. Sawan, Z.F Fawzy, and S.M. El-Sawy. 2015. Foliar application of glycine betaine for alleviating water stress of tomato plants grown under sandy soil conditions. Int. J. Chemtech Res. 8:52-67.

Rop, D.K., E.C. Kipkorir, and J.K. Taragon. 2016. Effects of deficit irrigation on yield and quality of onion crop. J. Agr. Sci. 8:112-126.

Sahin, U., K. Yasemin, M. Fatih, and C. Talip. 2016. Growth, yield, water use and crop quality responses of lettuce to different irrigation quantities in a semi-arid region of high altitude. J. Appl. Hort. 18(3):195-202.

Sayyari, M., M. Ghavami, F. Ghanbari, and S. Kordi. 2013. Assessment of salicylic acid impacts on growth rate and some physiological parameters of lettuce plants under drought stress conditions. IJACS 5(17):1951-1957.

Şenyiğit, U. and D. Kaplan. 2013. Impact of different irrigation water levels on yield and some quality parameters of lettuce (Lactuca sativa L. var. Longifolia) under unheated greenhouse condition: Infrastructure and ecology of rural areas. Polska Akademia Nauk, Oddział Krakowie 4:97-107.

Shams, M., E. Yildirim, M. Ekinci, M. Turan, A. Dursun, F. Parlakova, and R. Kul. 2016. Exogenously applied glycine betaine regulates some chemical characteristics and antioxidative defence systems in lettuce under salt stress. Hort. Environ. Biotechnol. 57:225-231.

Sharif, R., M. Mujtaba, M. Rahman, A. Shalmani, H. Ahmad, T. Anwar, D. Tianchan, and X. Wan. 2018. The multifunctional role of chitosan in horticultural crops: A review. Molecules 23:E872.

Sonmez, I., H. Kalkan, H. Demir, R. Kulcu, O. Yaldiz, and M. Kaplan. 2017. Mineral composition and quality parameters of greenhouse grown lettuce (Lactuca sativa L.) depending on fertilization with agricultural waste composts. Acta Sci. Polonorum Hortorum. 16:85-95.

Song, S.Q., Q.M. Sang, and S.R. Guo. 2006. Physiological synergisms of chitosan on salt resistance of cucumber seedlings. Acta Bot. Boreali-Occidentalia Sin. 26:435-441.

Wang, N., F. Cao, M. Eusi, A. Richmond, C. Qiu, and F. Wu. 2019. Foliar application of betaine improves water deficit stress tolerance in barley (Hordeum vulgare L.). Plant Growth Regulat. 89:109-118.

Wakrim, R., S. Wahbi, H. Tahi, B. Aganchich, and R. Serraj. 2005. Comparative effects of partial root drying (PRD) and regulated deficit irrigation (RDI) on water relations and water use efficiency in common bean (Phaseolus vulgaris L.). Agr. Ecosyst. Environ. 106:275-287.

Wutipraditkul, N., P. Wongwean, and T. Buaboocha. 2015. Alleviation of salt-induced oxidative stress in rice seedlings by proline and/or glycine betaine. Biol. Plant. 59:547-553.

Yao, W., T. Xu, S.U. Farooq, P. Jin, and Y. Zheng. 2018. Glycine betaine treatment alleviates chilling injury in zucchini fruit (Cucurbita pepo L.) by modulating antioxidant enzymes and membrane fatty acid metabolism. Postharvest Biol. Technol. 144:20-28.

You, L., Q. Song, Y. Wu, S. Li, C. Jiang, L. Chang, X. Yang, and J. Zhang. 2019. Accumulation of glycine betaine in transplastomic potato plants expressing choline oxidase confers improved drought tolerance. Planta 249:1963-1975.

Yu, J., I. Shainberg, Y.L. Yan, J.G. Shi, G.J. Levy, and A.I. Mamedov. 2011. Superabsorbents and semiarid soil properties affecting water absorption. Soil Sci. Soc. Amer. J. 75:2305-2313. 